\title{
The Effect of Cabbage Leaves Compress on Breast Engorgement in Postpartum Mother
}

\author{
Happy Dwi Aprilina ${ }^{1 *}$, Krislinggardini Krislinggardini ${ }^{2}$, Nur Isnaini $^{3}$, Suratmi Suratmi ${ }^{4}$ \\ ${ }^{1}$ Maternity Departement, Faculty of Health Science, Universitas Muhammadiyah Purwokerto, Banyumas, Jawa Tengah, Indonesia; \\ ${ }^{2}$ Departement of Management Nursing, Faculty of Health Science, Universitas Muhammadiyah Purwokerto, Banyumas, Jawa \\ Tengah, Indonesia; ${ }^{3}$ Department of Medical Surgical Nursing, Faculty of Health Science, Universitas Muhammadiyah Purwokerto \\ Banyumas, Jawa Tengah, Indonesia; ${ }^{4}$ RSUD Prof. Dr. Margono Soekarjo, Purwokerto, Banyumas, Jawa Tengah, Indonesia
}

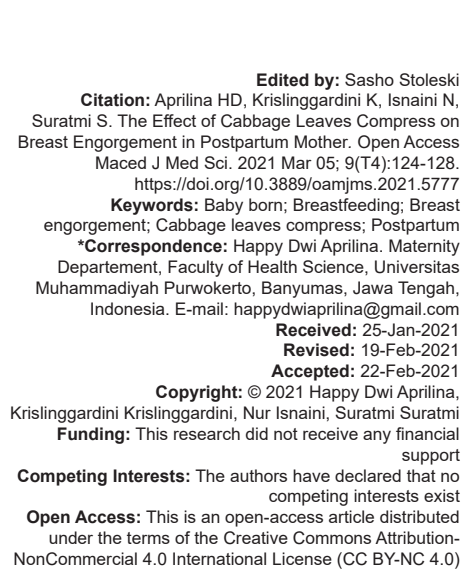

\section{Abstract}

BACKGROUND: Breast engorgement causes discomfort in the breastfeeding process. If untreated, it can make the baby reluctant to be breastfed. In turn, it may result in clogged milk which affects milk production and lead to mastitis/ infection of the milk glands.

AIM: The aim of the study was to know the effect of cabbage leaves compress on breast engorgement in postpartum mothers.

METHODS: Pre-experimental was done with one group. The pre- and post-test design approach was applied. The population of this study is postpartum mothers who experienced breast engorgement. A consecutive sampling was employed as the sampling technique. The instruments to collect the data are using the observation sheet and breast engorgement rating scale based on Hill and Humenick '94. The data were then analyzed the Wilcoxon test.

RESULTS: The majority of the characteristics of respondents who experience breast engorgement are postpartum mothers aged 20-35 years, with junior high school education, unemployed or housewives, and multiparous mothers. Before cabbage leaves compression, the majority of 29 mothers $(96.7 \%)$ experienced engorgement on a scale of 3 and declined to a scale of 2 after the intervention. The result of the effect of cabbage leaves compress on breast engorgement in postpartum mothers was effective with a value of $p=0.000$.

CONCLUSION: There is a significant effect of cabbage leaves compress on breast engorgement for the postpartum mothers.

\section{Introduction}

Babies need optimal nutrition for the development and growth of their organs. The need of the babies is fulfilled by breast milk (ASI) since breast milk contains vitamins, minerals, fats, and proteins that the babies need. At the age of 0-6 months, babies are given exclusive breastfeeding. Babies only consume breast milk without being given other foods or drinks except vitamins and medicines that are needed by babies [1]. The breastfeeding process sometimes experiences problems since postpartum such as sore nipples, blistered nipples, breast engorgement, and mastitis [2].

Breast engorgement occurs due to inadequate breastfed so that the remaining milk is clogged in the duct system which results in swelling. Using a tight bra and unclean nipples are among the factors that can cause blockage of the duct. It generally occurs on the $2^{\text {nd }}-4^{\text {th }}$ days after delivery, but there are also the cases that appear earlier at 48-96 $\mathrm{h}$ after delivery.

Static blood and lymph vessels will cause intra-caudal pressure to increase so that it can affect the segments in the breast. Pressure on all segments of the breast can cause the breast to feel full, tense, and painful, causing discomfort to the nursing mother. Breast engorgement also results in decreased milk production and decreased let down reflexes, putting the baby at risk of getting complementary foods, other than the breast milk [3].

Breast engorgement occurs in almost $90 \%$ of primiparous mothers and it generally appears on the $2^{\text {nd }}-4^{\text {th }}$ day after the mother gives birth. Breast engorgement that occurs at the beginning of the puerperium will cause pain in the postpartum mother because the breasts feel so full and hard. Besides, the baby is still not optimal in the breastfeeding process. At the beginning of the postpartum week, if the mother does not know information related to the breastfeeding process and fails to overcome the problems, then she will easily give up breastfeeding the baby [4]. Based on a preliminary study conducted at RSUD Prof. Dr. Margono Soekarjo Purwokerto, Jawa Tengah, Indonesia, in September 2018, there were 1287 spontaneous postpartum and section cesarean mothers, as well as 356 post-section cesarean mothers. In those 3 months, 
there were 335 mothers who experienced breast engorgement.

Breast engorgement, if not handled, may result in discomfort in the breastfeeding process; the baby is reluctant to be breastfed and clogged milk affects milk production and it may develop mastitis/ infection of the milk glands. Treatments in handling the breast engorgement can be done applying both nonpharmacological and pharmacological techniques. The pharmacology techniques can be done by collaborating with doctors, while non-pharmacology can be done by nurses independently. Non-pharmacology in the management of breast engorgement includes acupuncture, breast care, compresses with cabbage leaves, alternating warm and cold water compresses, Reserve Pressure Softening, back massage, and ultrasound therapy [5].

One method to overcome breast engorgement is by compressing the swollen breasts with cabbage leaves (cabbage leaves compress). Cabbage leaves compress is a method of compressing swollen breasts by compressing fresh cabbage leaves, then placing the cabbage leaves in a bra for about $30 \mathrm{~min}$ or until wilted. This treatment is carried out twice a day for 3 days. Before the treatment is carried out, one sheet of cabbage leaves is taken and makes a hole in the middle then wash it and the cabbage leaves is ready to be used for compressing. According to research by Lim et al. which states that cabbage compresses are effective in overcoming breast engorgement in primiparous mothers after giving birth by section cesarean [6].

Breast engorgement causes a discomfort for nursing mothers and may lead into a failure of the breastfeeding. Hence, it is very important to reveal the effect of cabbage leave compress on the breast engorgement among postpartum mothers.

\section{Methods}

The pre-experimental design with pre- and post-test in one group is the model applied in this research. The population is the postpartum mothers with breast engorgement, treated in Flamboyan Ward of the local hospital of RSUD Prof. Dr. Margono Soekardjo Purwokerto. A consecutive sampling was employed as sampling technique. Research samples with inclusive criteria: $\geq 1$ day postpartum mother treated in Flamboyan Room, Prof. Dr. Margono Soekardjo Hospital Purwokerto, mothers who breastfeed their babies and rooming in with their babies, mothers who are willing to be respondents, and postpartum mothers who are literate; they can read and write. In this study, the exclusion criteria were postpartum mothers with HIV and HBsAg (+), postpartum who received suppression of lactation, postpartum with breast abscess, and postpartum with dead babies. A consecutive sampling is the technique of choosing the sample and it gave 30 respondents of postpartum mothers.

This study used a research instrument based on Hill and Humenick (1994) with observation sheets and a breast engorgement scale with 6 criteria. These criteria are:

Criteria 1 = Flaccid breasts, no consistency in the breast. 2 = There is a slight change in the breast. $3=$ Hard breast, but no pain. $4=$ Hard breasts start to feel painful. $5=$ Hard and painful breasts. $6=$ Very hard and very painful. The research instrument was also equipped with the respondent's demographic data set by researcher. The form of the question was check list, where the demographic data contained the name of the respondent (initials), age, education, parity, address, and occupation. The independent variable (independent variable) in this study was breast engorgement in postpartum mothers.

This study aims to identify the characteristics of the respondents and to discover the effect of compressed cabbage leaves on breast engorgement in postpartum mothers. The analysis was done using Wilcoxon test because the normality test showed the data were not normal. This research has received permission from the ethics committee of Prof. Dr. Margono Soekarjo Purwokerto Hospital, Central Java, Indonesia, with number: 420/17530 VII / 2017.

\section{Results}

\section{Characteristics of respondents}

Based on Table 1, it demonstrated that this study consisted to the inclusion criteria and research exclusion criteria of 30 respondents after giving birth in the Flamboyan Room at RSUD Prof. Dr. Margono Soekarjo Purwokerto. The characteristics of mothers who experienced breast engorgement occurred at the age of 20-35 years totaled 14 mothers (46.7\%) and $<20,>35$ years as many as 16 mothers (53.3\%). Mother

Table 1: Characteristics of respondents

\begin{tabular}{lll}
\hline Characteristics & $\mathbf{n}$ & $\%$ \\
\hline Age & 14 & \\
a. $20-35$ years old & 16 & 46.7 \\
b. $<19$ and $>36$ years & & 53.3 \\
old & 30 & 100 \\
Total & & \\
Education & 8 & 26.7 \\
a. Elementary School & 11 & 36.7 \\
b. Junior High School & 9 & 30 \\
c. Senior High School & 2 & 6.6 \\
d. College/University & 30 & 100 \\
Total & & \\
Occupation & 3 & 10 \\
a. Yes & 27 & 90 \\
b. No & 30 & 100 \\
Total & & \\
Parity & 11 & 36.7 \\
$\quad$ a. Primipara & 19 & 63.3 \\
b. Multipara & 30 & 100 \\
Total & & \\
\hline
\end{tabular}


characteristics based on education who experienced breast engorgement were typically had junior high school education as many as 11 mothers (36.7\%). Mothers who experienced breast engorgement based on occupation criteria mostly were housewives totaled 27 mothers (90\%).

Based on the parity characteristic of the respondents, the majority of mothers who experienced breast engorgement were multiparous mothers (19 or $63.3 \%)$.

Scale of breast engorgement prior and postcabbage leaves compress on the postpartum mother

Table 2 indicated that most of the postpartum, the majority of 29 mothers (96.7\%) in the Flamboyan Room RSUD Prof. Dr. Margono Soekardjo Hospital Purwokerto before being given cabbage leaves compress, experienced swelling on a scale of 3 ; hard but not painful breasts. After being given the cabbage leaves compress intervention, the majority of 22 mothers $(73.3 \%)$ had a decrease in breast swelling on a scale of 2 ; there was a slight change in the breast.

Table 2: Scale of breast engorgement prior and post-cabbage leaves compress on postpartum mother

\begin{tabular}{llllll}
\hline Scale & Pre-cabbage & & & Post-cabbage & \\
\cline { 2 - 3 } \cline { 5 - 6 } & $\mathbf{n}$ & 0 & & $\mathbf{n}$ & $\%$ \\
\hline 1 & 0 & 0 & 0 & 0 \\
2 & 29 & 96.7 & 8 & 73.3 \\
3 & 1 & 3.3 & 0 & 26.7 \\
4 & 0 & 0 & 0 & 0 \\
5 & 0 & 0 & 0 & 0 \\
6 & & & 30 & 0 \\
Total 30 100 & & & & 100 \\
\hline
\end{tabular}

\section{The effect of cabbage leaves compress on breast engorgement in postpartum mothers}

Table 3 shows the value of $p=0.000$, meaning that there was an effect of cabbage leaves compress on breast engorgement in postpartum mothers in the Flamboyan Room of RSUD Prof. Dr. Margono Soekarjo, Purwokerto.

Table 3: The effect of cabbage leaves compress on breast engorgement in postpartum mother

\begin{tabular}{lllll}
\hline Scale & $\mathbf{n}$ & $\begin{array}{l}\text { Median } \\
(\text { min-max })\end{array}$ & Mean \pm s.d. & p \\
\hline Pre-intervention & 30 & $3(3-4)$ & $3.03 \pm 0.18$ & 0.000 \\
Post-intervention & 30 & $2(2-3)$ & $2.27 \pm 0.45$ & \\
\hline
\end{tabular}

\section{Discussion}

\section{Characteristics of respondents}

Mothers age

At the age of $<20$ and $>30$ years, this age is classified as the age at risk for childbirth for a mother.
At that age, anxiety in postpartum mothers will increase. Anxiety is one of the factors that may cause breast engorgement. This age is the reproductive age for women, where women over 25-30 years of age have the most initiative to breastfeed compared women aged 40 years so that it can stimulate breast engorgement [7]. Age does not affect breast engagement because what is more influential is a person's knowledge in preventing it so that the engorgement does not occur [8].

According to Rahmawati (2012), mother's age is highly determining maternal health because it is related to the conditions of pregnancy, childbirth, and postpartum as well as how to care for the baby and maintain the condition of the breast [9]. Mothers aged $<20$ years are still immature and not physically and socially prepared to face pregnancy and childbirth. While mothers who are 20-30 years old are called maturity age and are also called reproductive periods, where at this time people are expected to be able to solve problems faced emotionally relaxed, especially in dealing with pregnancy, childbirth, postpartum, and caring for their babies later [10].

Mother's age affects breast milk production where young mothers produce more milk than the older. The breasts often feel full and painful due to the production of large amounts of milk. If postpartum mothers aged 20-30 years cannot cope with the production of breast milk that continues to produce and are not balanced with their outflow and the mother's lack of knowledge about how to care for their breasts, there is a greater risk of swelling in the breasts. On the other hand, postpartum mothers who are $>30$ years old has less breast milk production or decreased milk production from productive age [11].

\section{Education}

At the level of education, the majority of mothers with junior high school education experienced engorgement. Efforts to provide knowledge for improved positive behavior change and high education affects the acceptance of new information and adjust to it; the higher a person's education level, the easier that person will understand the information and more knowledge they have [12].

The low level of education of mothers resulted in mothers' lack of knowledge in dealing with problems, especially in breastfeeding their babies. This knowledge is acquired both formally and informally. In the contrary, mothers who have a higher level of education are generally open to accepting changes or things to maintain their health. Education will also motivate a person to be curious to seek experience so that the information received will become knowledge. The level of education in the family, especially mothers, can be a factor affecting the nutritional status of children in the family [9]. 


\section{Occupation}

On the occupational status, most of the mothers who do not work experience engorgement. Mothers who do not work are more likely to be able to breastfeed their babies. For working mothers, the short length of maternity leave and childbirth has resulted in the mother having to return to work and deciding not to breastfeed her baby to any further extent. It is different with mothers who do not work, mothers who do not work have more time to take care of the household because they are not tied to busy work schedules and routines so they have a greater opportunity to pay attention to the condition of their breasts.

The occurrence of engorgement in Indonesia is mostly occurred on working mothers (36\%) due to their busy work and household activities [13].

\section{Parity}

The hormones associated with breastfeeding are prolactin and oxytocin. The hormone prolactin functions to produce breast milk in accordance with the baby's needs because this hormone work is not directly related to the volume of milk. If the prolactin hormone functions weakly, then the milk products cannot be excreted maximally [14].

Breast engorgement is a minor discomfort that occurs in women after childbirth, especially primiparous. This physiological condition is characterized by pain, swelling of the breast as a result of a sudden increase in milk volume, lymphatic, and vascular congestion and interstitial edema during the first 2 weeks after birth. The condition is caused by insufficient breast milk or congestion of the milk ducts. Breast pain during breastfeeding is a problem that interferes with the swelling [15].

At birth status, the majority occurred in multiparous mothers who experienced breast engorgement. Parity has no correlation to the occurrence of breast engorgement in postpartum mothers [16]. In primiparous mothers, there is a slowly increase in the amount of breast milk compared to multiparous mothers in breastfeeding which is often at the beginning of lactation can stimulate the development of prolactin receptor sites in the mammary glands [14].

\section{The effect of cabbage leaves compress on} breast engorgement in postpartum mothers

The usual response of the breast to sudden changes in hormones and the significant increase in milk volume is known as breast engorgement. This occurs within 3-5 days after birth when breast milk increases and it lasts about $24 \mathrm{~h}$. Blood flow to the breasts increases and causes swelling of the tissue around the ducts of the mammary glands. Clogged milk ducts prevent the milk from flowing out of the breast. Signs of breast engorgement are hard, painful, hot, shiny, and tense on the breasts. The areola and hard nipples make breastfeeding more difficult. The congested breast milk will cause an inhibition of milk production and if this prolonges, the milk supply will decrease [17].

The treatments to take by nurses in the case of engorgement problem are to regulate the breastfeeding every $2 \mathrm{~h}$, to release the breast milk to soften the breast, to do ice compresses for about 15-20 min, to apply a compressing with raw and fresh cabbage leaves, and to administer anti-inflammatory. The soft breasts and aerola will allow the baby to latch on the nipples more easily for the breastfeeding.

Based on the research of Ketsuwen et al., on 500 postpartum respondents, a half of them were given herbal compresses and another half were given warm compresses. It proved that the reduction in pain scale after being given herbal compresses was found to be greater than with warm compresses [18].

Fresh, raw cabbage leaves placed on the breast can reduce the swelling. The leaves are washed and cooled and then placed on the breast for 15-20 min. This treatment can be repeated two to three sessions. More frequent use of cabbage leaves can reduce milk supply. If the leaves are wilted, they should be replaced with the fresh ones. This treatment is also not recommendable for those with allergic to cabbage leaves or sulfa drugs or in case a rash is seen on the skin [17].

According to Davis and Marie, cabbage can be used for inflammation therapy. Cabbage contains amino acid of methionine which serves as an antibiotic and other ingredient such as sinigrin, mustard oil, and magnesium. The contents in cabbage are able to widen the capillaries, thereby increasing blood flow to and from the area, allowing the body to reabsorb the clogged fluid in the breast. In addition, cabbage leaves also release a cold gel that can absorb heat, which is indicated by mothers feeling becoming more comfortable and the cabbage leaves become wilted/cooked after $30 \mathrm{~min}$ sticking to the mother's breast [19].

Compressing of cabbage that is placed on the breast after breastfeeding is able to reduce pain due to breast engorgement, even after every milking [20]. Cabbage compress is able to reduce pain in swollen breasts [21]. This statement is in accordance with a research conducted by Arora, the treatment of hot and cold cabbage compress can reduce pain and breast engorgement $(p<0.001)$ [22]. This is in accordance with the research of Nanthini and Bhuvaneswari which states that cold cabbage leaves are an alternative treatment that can be used to reduce breast engorgement at Chennai Hospital [23].

\section{Conclusion}

- The characteristics of mothers who experienced breast engorgement were the 
majority at the age of 20-35 years, junior high school education, non-working mothers, and multiparous mothers.

- Before the cabbage leaves compress, the majority of 29 mothers $(96.7 \%)$ experienced swelling on a scale of 3; the breasts were hard but not painful. After being given the cabbage leaves intervention, the majority of 22 mothers (73.3\%) experienced a decrease in breast swelling on a scale of 2; there was a slight change in the breast. The results indicated that there was an effect of cabbage leaves compress on breast engorgement in postpartum mothers in the Flamboyan Room of Prof. Margono Soekarjo Hospital Purwokerto with $(p=0.000)$

\section{Suggestion}

- For respondents and community Improve knowledge about interventions in breast engorgement

- $\quad$ For Prof. Dr. Margono Soekarjo Hospital It is expected that this intervention can be one of the SOPs that can be applied to Prof. Dr. Margono Soekarjo hospital so that the mother felt comfortable in the breastfeeding process For further research

It is expected that further research found other interventions that can be compared to cabbage leaves compress.

\section{Acknowledgments}

This research was funded by LPPM UMP. The research team would like to thank all those who have helped carry out this research activity, especially to RSUD Margono Hospital, Banyumas.

\section{References}

1. World Health Organization/Unicef. Pelatihan Konseling Menyusui Modul 40 jam WHO/UNICEF. World Health Organization; 2011.

2. Pramitasari RD, Saryono. Perawatan Payudara. Yogyakarta: Mitra Cendekia; 2008.

3. Suradi, R. Bahan Bacaan Manajemen Laktasi. $2^{\text {nd }}$ ed. Jakarta : Perkumpulan Periantologi Indonesia; 2004.

4. Novita VT. Efektifitas Paket "Bunda Ceria" Terhadap Rasa Nyeri dan Pembengkakan Payudara Serta Produksi ASI Pada Ibu Post Partum Dijakarta. Tesis Keperawatan Dari Indonesia;
2011. https://doi.org/10.33860/jik.v12i2.22

5. Snowden, HM, Renfrew MJ, Woolridge MW.Treatment for breast engorgement during lactation. The Corbrane Database of Systematic Reviews, issue, Art. 2005. https://doi. org/10.1002/1465858.cd000046.pub2

6. Lim AR, Song JA, Hur MH, Lee MK, dan Lee MS. Cabbage compression early breast care on breast engorgement in primiparous women after cesarean birth: A controlled clinical trial. Int J Clin Exp Med 2015;8:21335-42.

PMid:26885074

7. Nommsen-Rivers LA, Chantry CJ, Peerson JM, Cohen RJ Dewey KG. Deleyed onset of lactogenesis among first-time mothers is related to maternal obesity and factors associated with ineffective breastfeending. Am J Clin Nutr. 2010;92(3):57484. https://doi.org/10.3945/ajcn.2010.29192

PMid:20573792

8. Desmawati. Pengaruh Kombinasi Areola Massage dan Rolling Massage Terhadap Pengerluaran ASI Secara Dini Pada ibu Post Partum di Puskesmas Pamulang-Banten; 2008. https://doi. org/10.32807/jmu.v2i2.99

9. Rahmawati A, Widyasih $\mathrm{H}$, Suherni. Perawatan Masa Nifas. Yogyakarta: Fitramaya; 2012.

10. Pechlivani F, Vivilaki V. Breastfeeding and breast cancer. Health Sci J. 2012;6:610-7.

11. Soetjiningsih. Tumbuh Kembang Anak. Jakarta: EGC; 2005.

12. Notoatmodjo S. Metodologi Penelitian Kesehatan. Jakarta: Rineka Cipta; 2020.

13. Kementerian Kesehatan RI. Profil Kesehatan Indonesia Tahun 2013. Jakarta: Kementerian Kesehatan RI; 2014. https://doi. org/10.33560/jmiki.v8i1.257

14. Hale TW, Hartmann PE. Textbook of Human Lactation. $1^{\text {st }}$ ed. Texas: Hale Publishing; 2007.

15. Fraser I.S, Benefits of cabbage for breast engogerment, 82 (5), Available at: http://www.ncbi.nlm.nih.gov/pmc/arrticles/ PMC4011100.

16. Indriyani D. Pengaruh Menyusui Dini dan Teratur Terhadap Produksi ASI Pada Ibu Post Partum Dengan Sectio Caesarea Di RSUD Dr. Soebandi Jember dan Dr. H. Koesnadi Bondowoso, Thesis, Depok: FIK Ul; 2006. https://doi.org/10.48079/vol2.iss2.40

17. Lowdermilk DL, Perry SE, Cashion K. Keperawatan Maternitas. $8^{\text {th }}$ ed. Singapore: Elsevier; 2013

18. Ketsuwan S, Baiya N, Paritakul P, Laosooksathit W Puaprorpong P. Effect of herbal compresses for maternal breast engogerment at postpartum: A randomized controlled trial. Breastfeed Med. 2018;13(5):361-5. https://doi.org/10.1089/ bfm.2018.0032

PMid:29688768

19. Marie D. Engogerment: The Cabbage Cure. Marie Davis RN, IBCLC; 2014. Available from: http://www.lactationconsultant. info/cabbagegecure. [Last accessed on 2017 Apr 15].

20. Jack N, Teresa P. The Ultimate Breastfeending Book of Answers. Jakarta: Buah Hati; 2008.

21. Elizabeth B. Cabbage Leaves for Breast Engorgement; 2007. http://www.midwifeinfo.com/articles/cabbageleaves-for-breastengorgement. [Last accessed on 2017 Apr 03]

22. Arora S, Vatsa M, Dadhwal V. Cabbage leaves vs hot and compress compresses in the treatment of breast engorgement. Nurs J India. 2009;100(3):160-2. https://doi.org/10.4103/0970-0218.42053 PMid: 19876476

23. Nathini dan Bhuvaneswari. A Study to Assess the Effectiveness of Compress Cabbage Leaves Vs Hot Water Application on Breast Engorgement among Postnatal Mothers in Selected Hospital, Chennai. International Journal of Science and Research (IJSR) ISSN (Online): 2319-7064 Index Copernicus Value (2013): 6.14 